\title{
THE TEMPORAL ORGANISATION OF SPEECH IN MONOLINGUAL AND BILINGUAL CHILDREN
}

\author{
KRISZTINA MENYHÁRT
}

\begin{abstract}
Research on the temporal organisation of speech with respect to age is extremely important as it may provide empirical confirmation for the various models of speech production. With the advancement of age, speech motor control becomes more secure, and so the child gradually approaches the level of articulation and speech tempo typical of adults. There have been numerous works published on the temporal relations of English-speaking, normally developing children; however, the relevant literature still lacks data on bilingual children. The present paper aims to fill this gap: it discusses the temporal organisation of speech in HungarianBulgarian bilingual children between the ages of 9 and 13 and monolingual children of the same age in a developmental perspective. The data on monolingual children in this paper also break new ground as only few papers have dealt with the speech rate of Hungarian children and none with that of Bulgarian children.
\end{abstract}

\section{Introduction}

In the process of acquiring language, the child learns to understand and produce the speech sounds, sound sequences, words, and syntactic structures of his language from which he constructs sentences and coherent utterances. As the child ages, his linguistic competence also improves, and as years go by, he becomes a skilled speaker-listener. By the age of three, the normally developing child is capable of correctly producing most speech sounds, talks a lot and does it with pleasure, and he frequently uses complicated syntactic structures (Downing-Valtin 1984). By the age of six, he has built a considerable vocabulary, and he develops the kind of language awareness that enables him to acquire written language, too. We can observe a high level of language awareness in 8-10-year-old children; in most cases, this is the age when foreign language teaching also begins. Although it is very similar to that of adults, the speech of 10-14-year-olds may show significant differences, typical of this age (for example, in the area of temporal relations), and so it may well be justified to refer to it as "teenage language" (Gósy 1999). 
The improvement of the linguistic competence of the child is not only displayed in the growth of his vocabulary or in the correct use of grammaticalsyntactic structures, but also in the strengthening of his speech motor control (Hall-Yairi 1997). The expansion of speech motor control affects the temporal relations of speech - the duration of sounds or sound sequences, the whole of speech rate, as well as pause-related characteristics. The discovery of the changes regarding the temporal organisation of the speech of a normally developing child may not only help to recognise and treat defective speech development, but it may also serve as a ground for comparison in the research of the speech development of bi- and multilingual children.

Several researchers have dealt with temporal patterning in the speech of monolingual children (e.g., for English: Boutsen-Hood 1997; Hall-Yairi 1997; Kowal et al. 1975; Tingley-Allen 1975; Walker et al. 1993; for Hungarian: Fónagy-Magdics 1960; Gósy 1991a; Laczkó 1991). The majority of these present a cross-section analysis. Their results can be summed up as follows: (i) fluency increases with age, together with speech rate; (ii) the acoustic-phonetic aspects of pauses differ from those of adults - we rarely find hesitations in the speech of children; (iii) the speech rate of adults is slower in brief utterances, while it is quicker in longer ones; children display this pattern only as they age; (iv) the speech rate of children shows quite considerable individual differences in the process of developing (cf. Smith-Kenney 1999's longitudinal analysis), as well as in relation to mean values.

The problem of speech rate motor control is discussed by various theories and models. According to the linear models, the changes occurring in the temporal relations of speech are caused by mechanisms that, with the help of articulatory movements, simply shorten or lengthen the duration of sounds (Lindblom 1968). Contrary to this, the advocates of the non-linear models claim that changes in speech rate reorganise the temporal structure of the whole articulatory process (cf. Gay 1981). As the views altered, it became clear that the motor control over the temporal organisation of speech was not directed by a single mechanism; it is still unclear, however, whether the various functions (such as those responsible for the temporal patterning of sounds, syllables, or the whole speech process) work in total isolation or in some sort of harmony (Hall-Yairi 1997).

The majority of speech production models (such as Dell 1986; Garrett 1982; Levelt 1989) have been created using data from monolingual adult speakers, and they contain practically no information on the speech production mechanisms of children or bilingual speakers (Poulisse 1997). Several attempts have been made at adapting these models to bilingual speakers (e.g., 
Green 1986; Bot 1992; Bot-Schreuder 1993; Poulisse-Bongaerts 1994); however, a great number of questions have been left unanswered, including those concerning the temporal patterning of bilinguals' speech. According to Bot (1992), the fact that bilingual persons use more than one language should not necessarily slow down their speech production compared to that of monolingual individuals. The available data pertaining to acquiring/learning a second language (Wiese 1984; Möhle 1984; Lennon 1990) show that there is a clear connection between the temporal organisation of speech (the duration of pauses, articulation rate, etc.) and competence in the given language. It is unclear how valid these findings are regarding the temporal structure of bilinguals, since, especially in the case of "stable" bilinguals (cf. Grosjean 1997), their competence in both languages may well be considerably high.

The topic of the present study is to investigate the temporal organisation of speech in Hungarian-Bulgarian bilingual children and Bulgarian and Hungarian monolingual children. The aim of the investigation is (i) to show the similarities and differences in the temporal organisation in the speech production of mono- and bilingual children, and (ii) to expand our understanding of the temporal organisation of speech in children. Based on the results of our previous research, we set up two hypotheses, according to which, (i) the articulation rate and speech rate in bilingual children are expected to be slower than in monolinguals; and (ii) we expected speech rate to increase by age, independently of mono- or bilingualism.

\section{Material and method}

Altogether 60 children took part in our experiment, 36 girls and 24 boys. Of them, 20 were Hungarian-Bulgarian bilingual children, some of whom went to the Bulgarian primary school in Budapest, while the others to Hungarian primary schools. 20 participants were Hungarian monolingual children, and another 20 were Bulgarian monolingual children. These children were the pupils of a primary school in Budapest and another in Sofia, respectively. The proportion of boys and girls was the same in each group (twelve girls and eight boys). At the time of the experiment, the children were third-, fourthand sixth-form pupils.

The majority of the bilingual children (13 participants) had acquired Hungarian and Bulgarian at the same time; Bulgarian was the first language in the case of five children, while it was Hungarian in the case of two. The result of these differences was that the set of the bilingual participants was 
not fully homogeneous in terms of competence in either Hungarian or Bulgarian. Since bilingualism is a relatively complex linguistic phenomenon, and thus the children in the experiment use the two languages differently and for different purposes, the creation of a homogeneous group is practically unaccomplishable.

We divided the children into two age groups (see Table 1). In the first age group, the age of the children was 9 to 10 years (by this time, language acquisition is by and large completed), while in the second group, there were 12 to 13-year-olds (the commencing of puberty, the second biological barrier), which enables one to trace linguistic development.

Table 1

Data relating to the age of the participants

\begin{tabular}{|l|c|c|}
\hline PARTICIPANTS & AVERAGE AGE & DEVIATION \\
\hline \hline Hungarian monolingual & $9 ; 11$ years & $9 ; 5-11 ; 0$ years \\
children & $12 ; 5$ years & $11 ; 10-13 ; 0$ years \\
\hline Bulgarian monolingual & $10 ; 1$ years & $9 ; 7-11 ; 2$ years \\
children & $12 ; 9$ years & $12 ; 5-12 ; 11$ years \\
\hline Hungarian-Bulgarian & $9 ; 10$ years & $9 ; 0-11 ; 0$ years \\
bilingual children & $12 ; 8$ years & $12 ; 5-13 ; 2$ years \\
\hline
\end{tabular}

The children were given the following task. They had to tell a continuous story based on a picture series with four items. We recorded the stories on tape, then noted down the recording, faithful to the original. Afterwards, we measured the time of the speech signals, the pauses, and the whole utterance to the ms using a digital signal processing device (CSL 4300B), then we added the number of sounds up. We investigated three factors: articulation rate, speech rate, and the quantitative and qualitative aspects of the pauses. Articulation rate is the speed of speech without pauses, while speech rate is that with pauses; their value is given in sound/second $(\mathrm{s} / \mathrm{s})$.

The following considerations played a role when processing the data: (i) the total and age-relative values of articulation rate and speech rate, and (ii) the acoustic-phonetic characteristics of the pauses. The statistical evaluation of the data was based on a one-way analysis of variance.

\section{Results}

Table 2 displays the average duration of the stories. The data clearly show that the majority of the children told the story within 20 to 30 seconds, and so 
there is no difference here between mono- and bilingual children. This suggests that the duration of the narratives mostly depends on the age of the children, and has no connection to mono- or bilingualism. The standard deviation data are spread within wide margins for each group, which is evidence for the existence of individual differences.

Table 2

The average duration of the stories

\begin{tabular}{|l|c|c|c|c|}
\hline PARTICIPANTS: & $\begin{array}{c}\text { HUNGARIAN } \\
\text { (MONOLINGUAL) }\end{array}$ & $\begin{array}{c}\text { HUNGARIAN } \\
\text { (BILINGUAL) }\end{array}$ & $\begin{array}{c}\text { BULGARIAN } \\
\text { (BILINGUAL) }\end{array}$ & $\begin{array}{c}\text { BULGARIAN } \\
\text { (MONOLINGUAL) }\end{array}$ \\
\hline \hline AVERAGE $(\mathrm{s}):$ & 22.6 & 23.3 & 28.2 & 24.1 \\
\hline DEVIATION $(\mathrm{s}):$ & $8.3-47.3$ & $10-66.7$ & $10-51.7$ & $13.2-50.3$ \\
\hline
\end{tabular}

According to the data, there is basically no difference between the average articulation rates of monolingual children. This tendency shows up in bilingual children's Hungarian and Bulgarian articulation rates, too. The divergence between the various data is not significant statistically either (for monolinguals: $\mathrm{p}=0.8210$, for bilinguals: $\mathrm{p}=0.9657$ ). If, however, we compare the mean values of the articulation rates of monolingual and bilingual speakers (cf. Figure 1), we find significant differences (for Hungarian: $p=0.0287$, for Bulgarian: $\mathrm{p}=0.0434$ ).

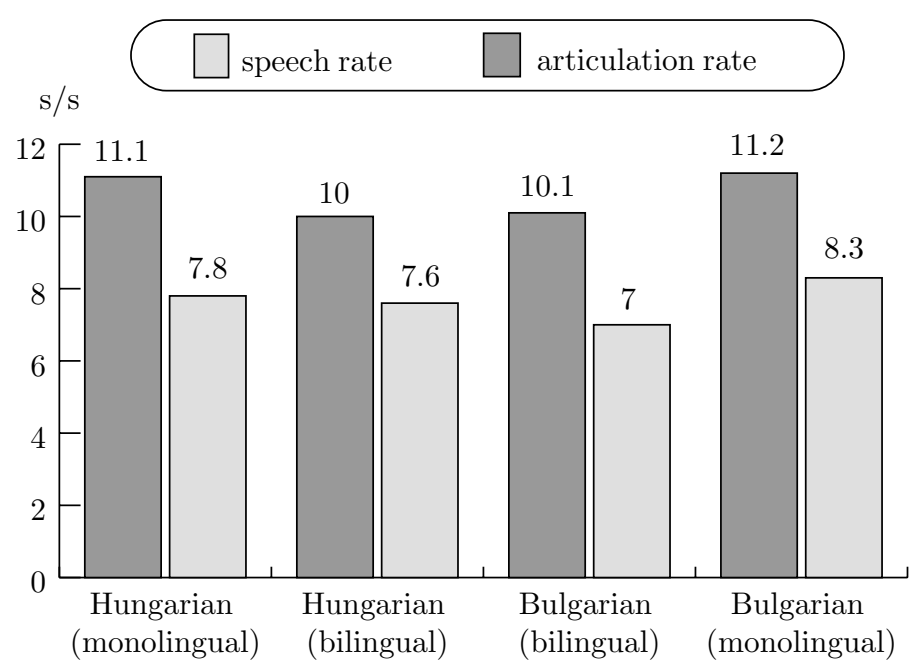

Fig. 1

The aggregated mean values of articulation and speech rate 
The data on speech rate have significantly altered compared with articulation rate (cf. Figure 1). The difference between the speech of the two monolingual groups and the Hungarian and Bulgarian speech of the bilinguals have increased (although not significantly: monolinguals: $\mathrm{p}=0.3860$; bilinguals: $\mathrm{p}=0.6420$ ). The difference between the speech rate of Bulgarian monolingual speakers and that of Bulgarian bilinguals has remained nearly the same, while the difference between Hungarian monolinguals and bilinguals has decreased (but even this is not significant: for Bulgarian: $\mathrm{p}=0.577$, for Hungarian $\mathrm{p}=0.3109$ ).

We may conclude that as far as the mean values of articulation rate and speech rate are concerned, bilingual children are slower in both languages than monolingual ones. The reason for this is undoubtedly bilingualism.

We can offer a much subtler analysis with the help of the standard deviation values of articulation rate and speech rate (Table 3 ).

Table 3

The standard deviation of articulation rate and speech rate

\begin{tabular}{|l|c|c|c|c|}
\hline PARTICIPANTS: & $\begin{array}{c}\text { HUNGARIAN } \\
\text { (MONOLINGUAL) }\end{array}$ & $\begin{array}{c}\text { HUNGARIAN } \\
\text { (BILINGUAL) }\end{array}$ & $\begin{array}{c}\text { BULGARIAN } \\
\text { (BILINGUAL) }\end{array}$ & $\begin{array}{c}\text { BULGARIAN } \\
\text { (MONOLINGUAL) }\end{array}$ \\
\hline \hline ARTIC. TEMPO (S/s): & $8.9-13.7$ & $7.1-13.4$ & $7-13.8$ & $8.4-13.2$ \\
\hline SPEECH RATE $(\mathrm{S} / \mathrm{s}):$ & $5.9-11$ & $4.6-11.1$ & $2.5-10.3$ & $5.8-11.6$ \\
\hline
\end{tabular}

The values of articulation rate and speech rate fluctuate within broad limits in each group. The differences between monolingual and bilingual children are evident not at the highest deviation threshold values, but in the lower regions, that is to say, conspicuously slow values also occur in articulation rate and speech rate in bilinguals. In the case of articulation rate, the divergence between monolingual and bilingual children was $1.8 \mathrm{~s} / \mathrm{s}$ (Hungarian) and $1.4 \mathrm{~s} / \mathrm{s}$ (Bulgarian). As far as speech rate is concerned, the speech of the slowest Bulgarian monolingual child was $3.3 \mathrm{~s} / \mathrm{s}$ faster than the slowest bilingual, while in the case of Hungarian, we did not notice such a significant difference. This fact shows that in the Bulgarian speech of bilingual children there are longer pauses than in their Hungarian speech.

The temporal organisation of speech processes - such as articulation rate and speech rate - changes with age during language acquisition (cf. Walker et al. 1993; Tingley-Allen 1975), but similar changes are a feature of later ages, too (Gocsál 2000). The results concerning the age groups in our experiment carry important information. Figure 2 shows the average values of articulation rate, broken down into age groups. 


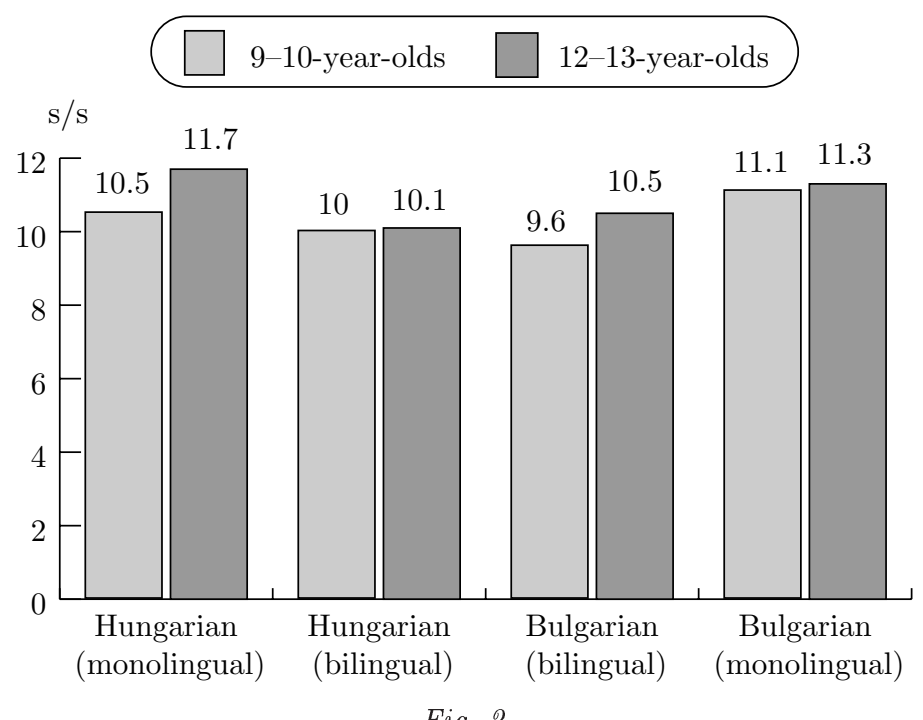

Articulation rate with respect to age groups

The articulation rate of 12-13-year-old children is faster than that of 910-year-olds, independent of mono- or bilingualism. The reason for this is perhaps that the speech planning and speech production processes of older children are more rapid (cf. Boutsen-Hood 1997; Menyhárt 2000), and this is manifested in their articulation rate, too.

The typical difference between the younger and older groups was, however, not statistically significant. The greatest difference surfaced between the two age groups of Hungarian monolingual children $(1.2 \mathrm{~s} / \mathrm{s} ; \mathrm{p}=0.0585)$, while in other groups the difference was below $1 \mathrm{~s} / \mathrm{s}$ (Bulgarian monolinguals: $0.2 \mathrm{~s} / \mathrm{s} ; \mathrm{p}=0.7672$; bilingual Bulgarian: $0.9 \mathrm{~s} / \mathrm{s} ; \mathrm{p}=0.3102$; bilingual Hungarian: $0.1 \mathrm{~s} / \mathrm{s} ; \mathrm{p}=0.9138)$.

In Figure 3 (overleaf) we illustrate the distribution of the total mean values of speech rate with respect to age groups. The data show a similar tendency as those on articulation rate, that is to say, it was the older children in all age groups that spoke more rapidly. The differences are not significant here either (Hungarian monolinguals: $\mathrm{p}=0.0838$, Bulgarian monolinguals: $\mathrm{p}=0.6905$, Hungarian speech of bilinguals: $\mathrm{p}=0.8433$; Bulgarian speech of bilinguals: $p=0.0921)$. A language dominance is also observable in bilingual children: while for 12-13-year-old children we got equal speech rate values for 
9-10-year-olds $\square$ 12-13-year-olds

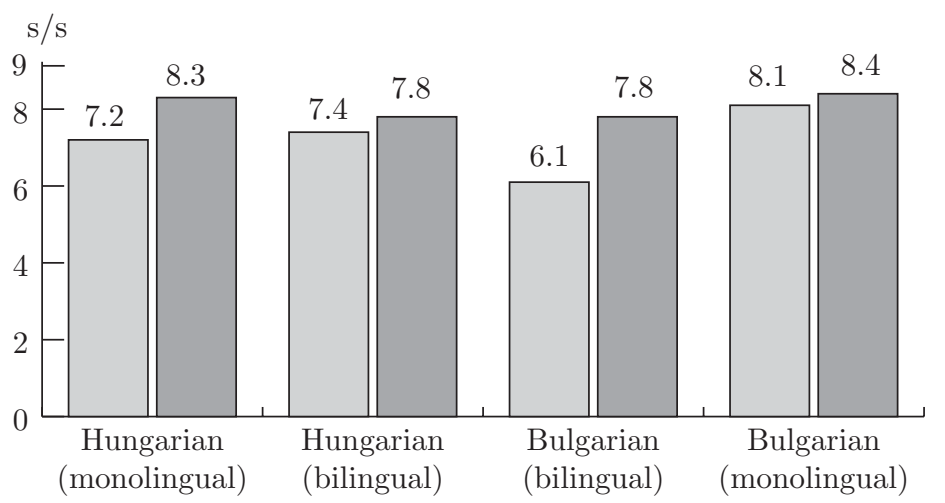

Fig. 3

Speech rate with respect to age groups

both languages, the Bulgarian speech rate of 9-10-year olds is slower than the Hungarian (there was not such a great difference in articulation rate).

We also investigated the differences between boys and girls, with respect to both articulation rate and speech rate (Table 4). On the basis of the relevant literature (cf. Kowal et al. 1975; Gocsál 2001 for Hungarian), we had thought that girls should talk faster. The data did not verify our hypothesis, because we could not prove a straightforward tendency based on our findings. Practically, there was no difference based on gender in the speech of monolinguals and bilinguals. We noticed a greater divergence only in the Bulgarian speech of bilingual children (in this case, unquestionably, the girls talked more rapidly). It appears that in the ages we investigated the gender differences typical of adults do not occur as yet.

Table 4

Gender-based differences in articulation rate and speech rate $(\mathrm{s} / \mathrm{s})$

\begin{tabular}{|l|c|c|c|c|c|c|c|c|}
\hline & \multicolumn{2}{|c|}{$\begin{array}{c}\text { HUNGARIAN } \\
\text { (MONOL.) }\end{array}$} & \multicolumn{2}{c|}{$\begin{array}{c}\text { HUNGARIAN } \\
\text { (BILING.) }\end{array}$} & \multicolumn{2}{c|}{$\begin{array}{c}\text { BULGARIAN } \\
\text { (BILING.) }\end{array}$} & \multicolumn{2}{c|}{$\begin{array}{c}\text { BULGARIAN } \\
\text { (MONOL.) }\end{array}$} \\
\cline { 2 - 9 } & $\begin{array}{c}\text { artic. } \\
\text { Gempeech }\end{array}$ & $\begin{array}{c}\text { artic. } \\
\text { tempo }\end{array}$ & $\begin{array}{l}\text { speech } \\
\text { tempo }\end{array}$ & $\begin{array}{c}\text { artic. } \\
\text { tempo }\end{array}$ & $\begin{array}{c}\text { speech } \\
\text { tempo }\end{array}$ & $\begin{array}{c}\text { artic. } \\
\text { tempo }\end{array}$ & $\begin{array}{l}\text { speech } \\
\text { tempo }\end{array}$ \\
\hline \hline GIRLS & 11.1 & 7.9 & 10.4 & 7.3 & 11.1 & 8 & 11.1 & 8.2 \\
\hline BOYS & 11.2 & 7.8 & 9.7 & 7.5 & 8.2 & 5.9 & 11.5 & 8.7 \\
\hline
\end{tabular}


The comparison of the values of articulation rate and speech rate of the individuals may be indicative of their language dominance and linguistic skills. Figure 4 shows the individual values of Hungarian and Bulgarian articulation rate.

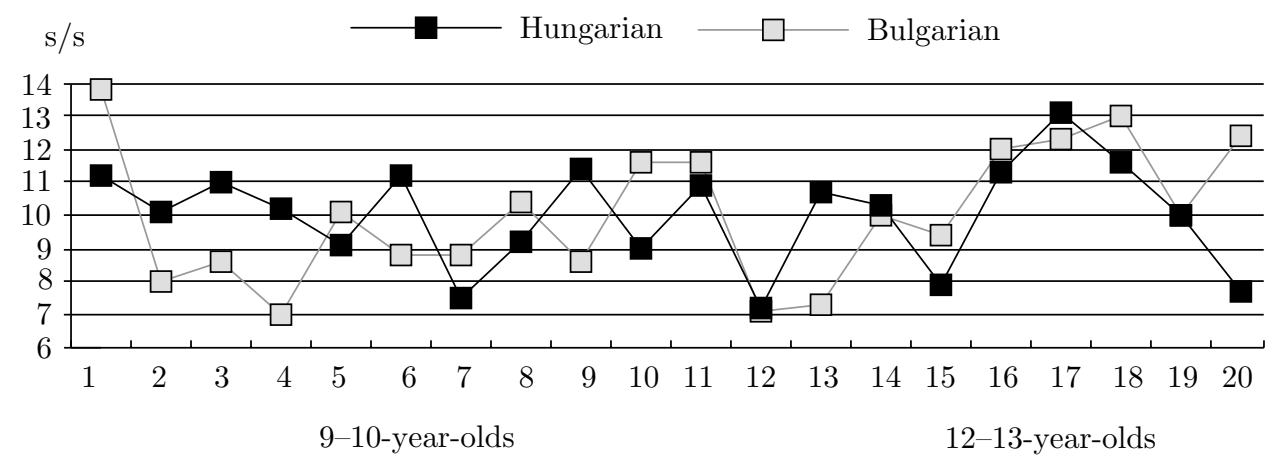

Fig. 4

The individual values of articulation rate in the Hungarian and Bulgarian speech of bilingual children

We can notice smaller (below $1 \mathrm{~s} / \mathrm{s}$ ) differences between the articulation rates of the two languages in the case of eleven children, while the differences are higher in nine participants. Apparently, the occurrence of the greater differences is connected to age: seven children belong to the younger generation, while the articulation rate was significantly higher only in the case of two older children (marked with "13" and "20" in Table 4). As far as the languages are concerned, ten children spoke rapidly in Hungarian and ten in Bulgarian.

If we compare the individual values of articulation rate and speech rate (Figure 5, overleaf), we can see that the difference is significant in the case of 15 children as far as speech rate is concerned $(3 \mathrm{~s} / \mathrm{s}$, or even higher). The two values are drawing near to each other in five participants. Eleven bilingual speakers talked more rapidly in Hungarian than in Bulgarian, whereas the Bulgarian speech rate was higher in the case of nine. We found only one child whose articulation rate was higher in Bulgarian, and the speech rate was more rapid in Hungarian. There are great individual differences both in articulation rate and speech rate. The reason for this, on the one hand, is to be found in the differences between linguistic skills, on the other, in the characteristics of the temporal organisation typical of children's speech (cf. Smith-Kenney 1999; Hall-Yairi 1997 for English).

The differences evident in the values of articulation rate and speech rate are caused by the pauses occurring in speech. There are two basic types of 


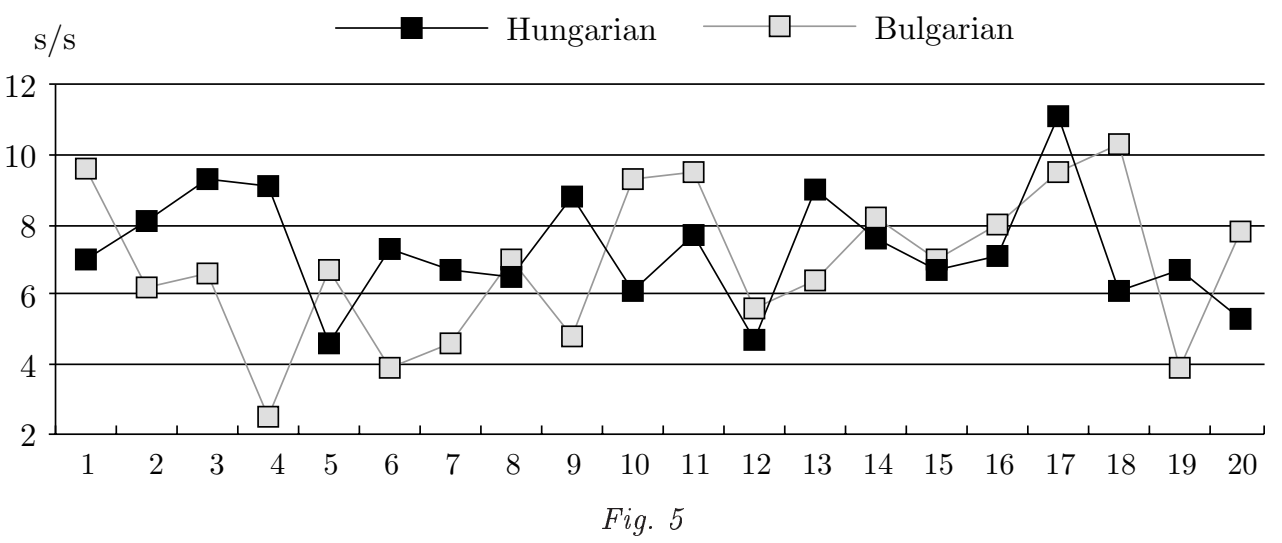

The individual values of speech rate in the Hungarian and Bulgarian speech of bilingual children

pauses: silent pauses (a total lack of signal), and hesitation or filled pauses, which may comprise the realisation of various speech sounds, and which may be caused by a gap in the logical course of thought or a sudden event (Sallai - Szende 1990).

Pauses comprised approximately one third of the speech of the children taking part in the experiment: $31 \%$ in Hungarian monolinguals, $27 \%$ in Bulgarian monolinguals, $29 \%$ in the Hungarian speech of bilinguals, and $34 \%$ in their Bulgarian speech. These percentages agree with those registered for the pauses occurring in the spontaneous speech of native adult speakers of Hungarian (Gósy 2000a).

We also investigated the qualitative distribution of pauses, and found that, independent of mono- or bilingualism, the majority of the pauses in the speech of children consisted of silent pauses-88\%-, and only $12 \%$ of them were hesitations. We found this in all of the children, there were no individual differences here. We also found that this kind of distribution of pauses is typical of child language (see Laczkó 1991), the percentage of hesitations in the spontaneous speech of adults is greater, comprises around 30\% (Gósy 2002). In the rest of the paper, we will treat silent and filled pauses equally, and we make no difference between them.

Figure 6 displays the mean values of the children's pauses according to age groups. Hungarian monolingual children produced the shortest pauses, the average pauses of the Bulgarian monolinguals were somewhat longer. Bilingual 


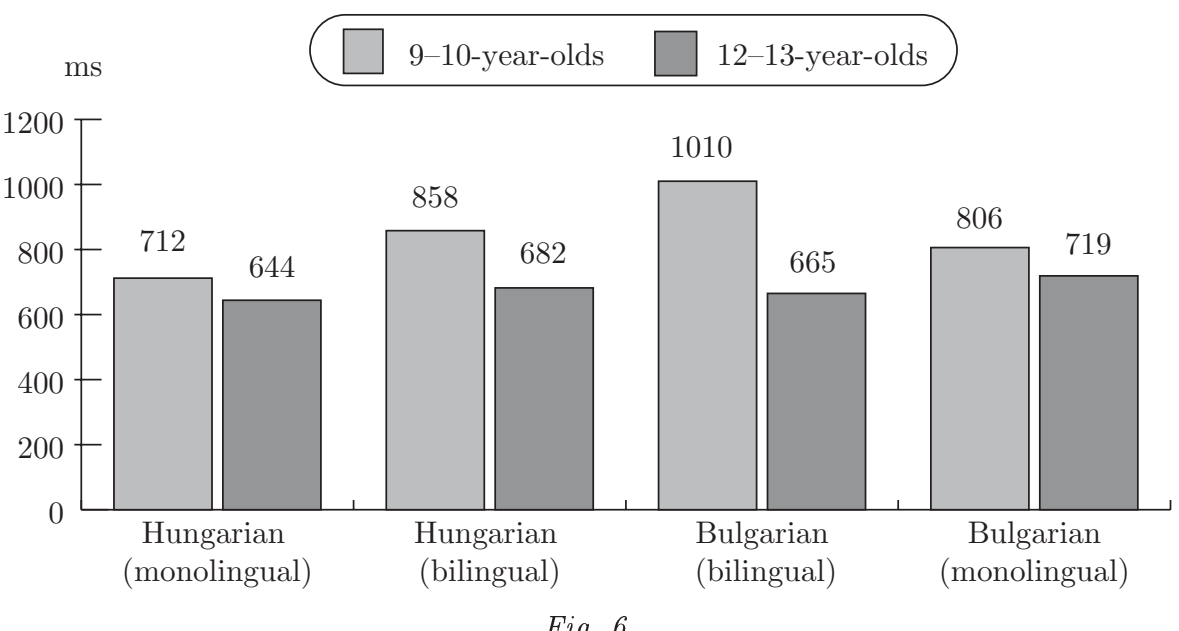

The average values of pauses with respect to age

children had longer pauses on average in both languages than the monolingual ones. The differences are not significant in either case, however.

The average duration of the pauses decreases by age. This is particularly evident in the case of bilingual children, and suggests that the coordination of speech planning and production requires longer time for younger bilinguals.

Table 5 shows the standard deviation values of pauses according to age groups. The broadest margins occur in the pauses of Bulgarian monolingual speakers (from 275 to $2351 \mathrm{~ms}$ ), similar values were found in the pauses of the Bulgarian speech of bilinguals.

Table 5

The standard deviation values of pauses (ms)

\begin{tabular}{|l|c|c|c|c|}
\hline PARTICIPANTS: & $\begin{array}{c}\text { HUNGARIAN } \\
\text { (MONOLINGUAL) }\end{array}$ & $\begin{array}{c}\text { HUNGARIAN } \\
\text { (BILINGUAL) }\end{array}$ & $\begin{array}{c}\text { BULGARIAN } \\
\text { (BILINGUAL) }\end{array}$ & $\begin{array}{c}\text { BULGARIAN } \\
\text { (MONOLINGUAL) }\end{array}$ \\
\hline \hline 9-10-YEAR-OLDS: & $264-1163$ & $314-1189$ & $505-2330$ & $413-2351$ \\
\hline 12-13-YEAR-OLDS: & $437-870$ & $367-1000$ & $427-1004$ & $275-1656$ \\
\hline
\end{tabular}

In the Hungarian speech samples, the distribution of pauses is more limited than in the Bulgarian (independently of mono- or bilingualism). Comparing the data, we can see that a Hungarian monolingual child produced the shortest pause, whereas the longest one occurred in the speech of a Bulgarian monolingual participant. The distributional values of bilingual children's 
pauses turned out to be similar to those of monolinguals'; however, they occurred within narrower margins.

The temporal distribution of pauses provides valuable information on how children use time, that is, how much time they need to organise direct spontaneous speech. The temporal distribution of pauses occurring in the speech of Bulgarian monolingual children and in the Bulgarian speech of bilinguals is shown in Figure 7, whereas the distribution of pauses in the speech of Hungarian monolinguals and the Hungarian speech of bilinguals is displayed in Figure 8.

The frequency of pauses decreases proportionally by the increase of time, there is no difference in this respect between either monolingual or bilingual children. We can conclude that this factor is independent of language, bilingualism, or age (for adults, cf. Gósy 1998).

The frequency of pauses was the greatest between 200 and $300 \mathrm{~ms}$, and there was no difference between mono- and bilingual children here either. We can observe another relative peak, around $1000 \mathrm{~ms}$, in both figures. In all probability, this indicates a pause for thinking in the process of speech design.

The fact that bilingual children produced relatively more and rather long pauses (above $3000 \mathrm{~ms}$ ) may be indicative of the difference regarding the linguistic skills between the monolingual and bilingual participants. Presumably, they find it difficult to organise what they want to say (especially in Bulgarian).

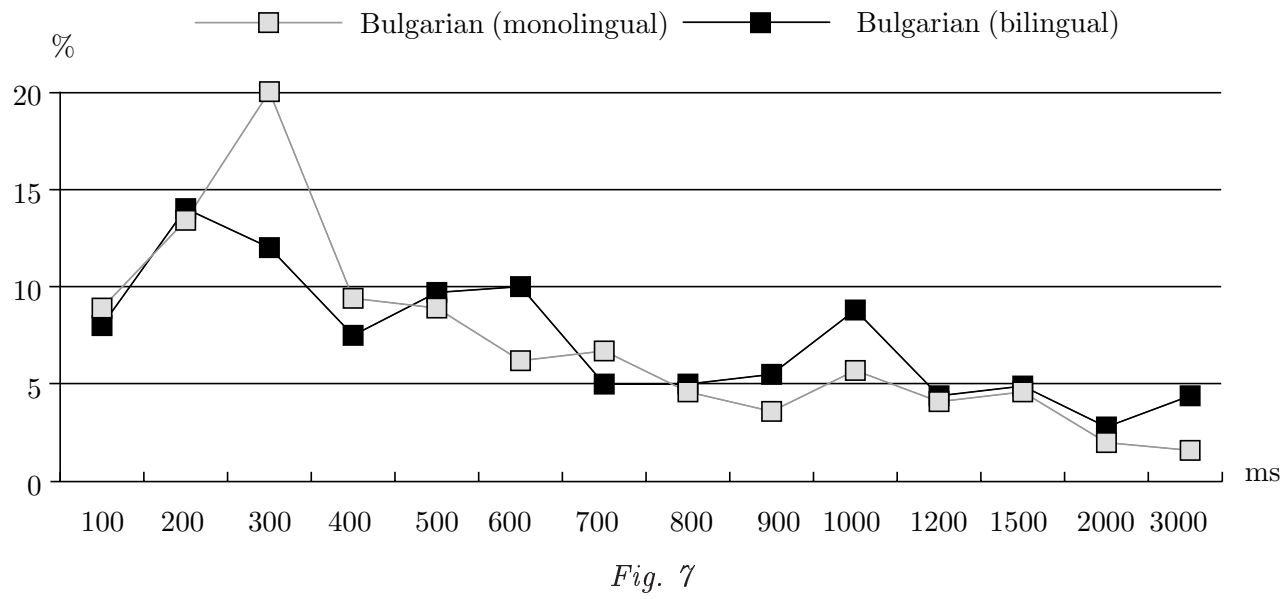

The distribution of pauses in the Bulgarian speech of mono- and bilinguals 


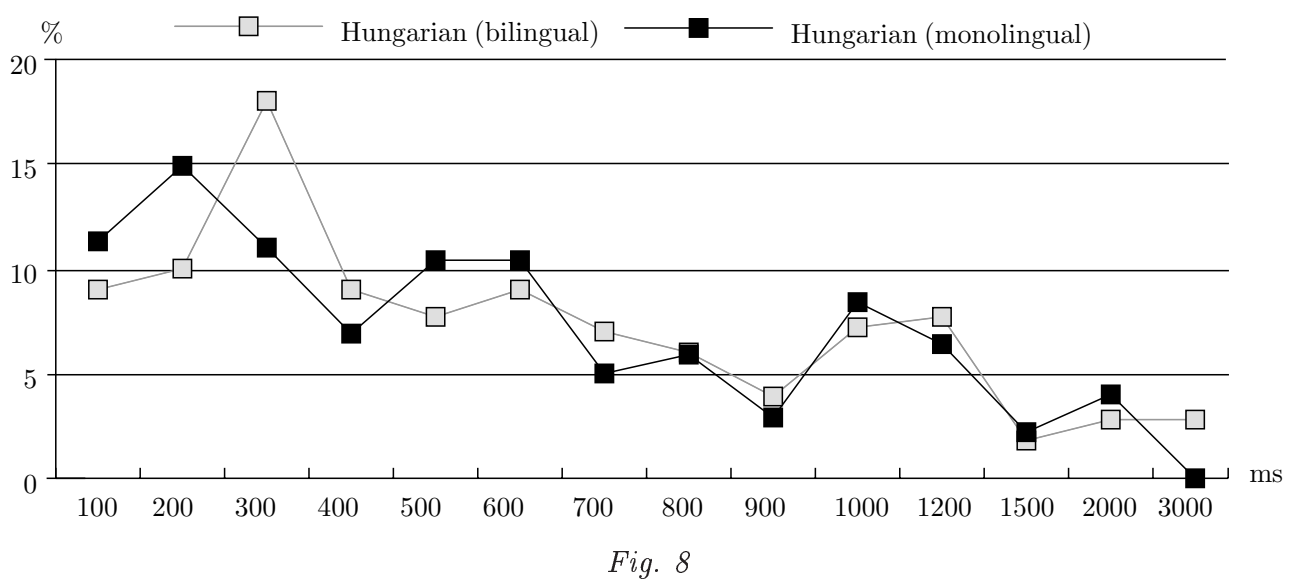

The distribution of pauses in the Hungarian speech of mono- and bilinguals

A question often raised concerns the problem of where exactly pauses occur in speech. Since pause is a segmentation sign at the same time (Fónagy 1967), we expect that the greater majority of pauses occur at phrase boundaries. However, this is not the case in the spontaneous speech of Hungarian-speaking adults (cf. Gósy 1999), pauses are rather more frequent within phrases. Nevertheless, children have pauses at boundaries of phrases rather than within them, and this distinguishes them from adults (see Table 6).

Table 6

The place of pauses in the stories

\begin{tabular}{|l|c|c|c|c|}
\hline PLACE & $\begin{array}{c}\text { HUNGARIAN } \\
\text { (MONOLINGUAL) }\end{array}$ & $\begin{array}{c}\text { HUNGARIAN } \\
\text { (BILINGUAL) }\end{array}$ & $\begin{array}{c}\text { BULGARIAN } \\
\text { (BILINGUAL) }\end{array}$ & $\begin{array}{c}\text { BULGARIAN } \\
\text { (MONOLINGUAL) }\end{array}$ \\
\hline \hline PHRASE BOUNDARIES & $65.5 \%$ & $64.5 \%$ & $51 \%$ & $58.5 \%$ \\
\hline WITHIN PHRASES & $34.5 \%$ & $35.5 \%$ & $49 \%$ & $41.5 \%$ \\
\hline
\end{tabular}

The reason why pauses occur at phrase boundaries may derive from the peculiarity of the task (picture description), since most children used complete, complex sentences to tell the story. An exception to this is the Bulgarian speech of bilingual children, where the number of pauses occurring at phrase boundaries and within phrases is approximately the same. This is caused without doubt by the partial lack of linguistic skills, as the children have difficulties at speaking in the non-dominant language. From time to time, they do not know or cannot activate a particular word, and the result of this is that pauses occur within phrases. 


\section{Conclusions}

The following conclusions may be drawn based on our experiment.

We verified our first hypothesis, namely, we found that the articulation rate and speech rate of bilingual children in both Hungarian and Bulgarian is slower than monolinguals'. The reason for this is undoubtedly bilingualism. The advantage that the child socialises in two languages, and acquires two languages, entails that his speech processes slow down when we compare them with monolingual children. This slowing down is only significant statistically in the case of articulation rate, but it can also be observed in speech rate and pause production as a tendency. If we compare the Hungarian and Bulgarian speech of bilingual children, we find that the articulation rate for both languages is basically the same, there is, however, a difference in the values of speech rate - their Hungarian speech is somewhat faster. This fact indicates the existence of a dominant language environment.

The significant difference between articulation rate and speech rate verifies the important role of pauses. The greatest majority of pauses $(88 \%)$ are silent, which is a fact independent of mono- or bilingualism. Another aspect, also typical of child language, is that pauses frequently occur at phrase boundaries, which indicates the working of particular speech planning and production mechanisms (characteristic of the given age) on the one hand, and may be the effect of the peculiarity of the picture description task, on the other.

We also verified our hypothesis concerning age: it was the older participants whose articulation rate and speech rate were higher, both in the case of monolingual and bilingual children. The reason for this may be that 12-13-year-old speakers are slowly approaching the values of adult speakers. Although there were differences between girls and boys, we could not find a unanimous tendency based on the data.

We observed great individual differences in the temporal organisation of the speech of monolinguals, but especially in that of bilinguals, not only between the various speakers, but also within one individual, with respect to the two languages. These results show the importance of language skills on the one hand, and the complexity of bilingualism, on the other. The great individual differences and the fact that bilingual children are somewhat slower than their monolingual mates also calls attention to the slower workings of their speech planning and production mechanisms, which may well influence their learning processes. 


\section{References}

Bot, Kees de 1992. A bilingual production model: Levelt's speaking model adapted. In: Applied Linguistics 13:1-24.

Bot, Kees de-Robert Schreuder 1993. Word production and the bilingual lexicon. In: Robert Schreuder-Bert Weltens (eds) The bilingual lexicon, 191-214. John Benjamins, Amsterdam.

Boutsen, Frank R. - Stephen B. Hood 1997. Determinants of speech rate and fluency in fast and slow speaking normally fluent children. In: Hulstijn et al. (1997, 557-65).

Dechert, Hans W.-Dieter Möhle-Manfred Raupach (eds) 1984. Second language productions. Narr, Tübingen.

Dell, Garry S. 1986. A spreading-activation theory of retrieval in sentence production. In: Psychological Review $93: 283-321$.

Downing, John-Renate Valtin (eds) 1984. Language awareness and learning to read. Springer Verlag, New York.

Fónagy, Iván 1967. Áthajlás, szünet, szerkezet [Run-on, pause, structure]. In: Nyelvtudományi Közlemények 69 : 313-43.

Fónagy, Iván - Klára Magdics 1960. Speed of utterance in phrases of different lengths. In: Language and Speech 3:179-92.

Garrett, Michael F. 1982. Production of speech: observations from normal and pathological language use. In: A. V. Ellis (ed.) Normality and pathology in cognitive functions, 57-98. Academic Press, London.

Gay, Thomas 1981. Mechanisms in the control of speech rate. In: Phonetica 38:148-58.

Gocsál, Ákos 2000. A beszéd időviszonyai különböző életkorú személyeknél [The temporal relations of speech in persons of different ages]. In: Gósy (2000b, 39-51).

Gocsál, Ákos 2001. Gyorsabban beszélnek-e a nők, mint a férfiak? [Do women talk faster than men?]. In: Mária Gósy (ed.) Beszédkutatás 2001 [Speech research 2001], 61-73. MTA Nyelvtudományi Intézet, Budapest.

Gósy, Mária 1991a. The perception of tempo. In: Gósy (1991b, 63-107).

Gósy, Mária (ed.) 1991b. Temporal factors in speech. MTA Nyelvtudományi Intézet, Budapest.

Gósy, Mária 1998. A beszédtervezés és beszédkivitelezés paradoxona [The paradox of speech planning and speech production]. In: Magyar Nyelvőr 122:3-15.

Gósy, Mária 1999. Pszicholingvisztika [Psycholinguistics]. Corvina, Budapest.

Gósy, Mária 2000a. A beszédszünetek kettős funkciója [The double role of speech pauses]. In: Gósy $(2000 \mathrm{~b}, 1-15)$.

Gósy, Mária (ed.) 2000b. Beszédkutatás 2000 [Speech research 2000]. MTA Nyelvtudományi Intézet, Budapest.

Gósy, Mária 2002. A megakadás-jelenségek eredete a spontán beszéd tervezési folyamataiban [The origins of hesitation phenomena in spontaneous speech planning processes]. In: Magyar Nyelvőr $126: 192-203$.

Green, David 1986. Control, activation and resource: A framework and a model for the control of speech in bilinguals. In: Brain and Language $27: 210-69$.

Groot, Annette de--Judith Kroll (eds) 1997. Tutorials in bilingualism. Erlbaum, New York. 
Grosjean, François 1997. Processing mixed language. In: de Groot-Kroll (1997, 225-54).

Hall, Kelly D. - Ehud Yairi 1997. Speaking rate and speech motor control: Theoretical considerations and empirical data. In: Hulstijn et al. (1997, 547-57).

Hulstijn, Wouter - Herman F.M. Peters - Pascal H.H.M. van Lieshout (eds) 1997. Speech production: motor control, brain research and fluency disorders. Elsevier, Amsterdam.

Kowal, S. - D. C. O'Connel- E. F. Sabin 1975. Development of temporal patterning and voice hesitations in spontaneous narratives. In: Journal of Psycholinguistic Research 4: 195-207.

Laczkó, Mária 1991. The interrelation of articulation rate and pauses in children's speech. In: Gósy (1991b, 139-53).

Lennon, Paul 1990. Investigating fluency in EFL: a quantitative approach. In: Language Learning $40: 387-417$.

Levelt, Willem J.M. 1989. Speaking. From intention to articulation. MIT Press, Cambridge MA.

Lindblom, Björn 1968. Temporal organisation of syllable production. Royal Institute of Technology, Stockholm.

Menyhárt, Krisztina 2000. A beszéd temporális sajátosságai kétnyelvűeknél (kisiskoláskortól időskorig) [The temporal characteristics of speech in bilinguals (from primary school to old age)]. In: Gósy (2000b, 51-63).

Möhle, Dieter 1984. A comparison of the second language speech production of different native speakers. In: Dechert et al. (1984, 26-49).

Poulisse, Nanda 1997. Language production in bilinguals. In: de Groot-Kroll (1997, 201-24).

Poulisse, Nanda - Theo Bongaerts 1994. First language use in second language production. In: Applied Linguistics 15:36-57.

Sallai, János-Tamás Szende 1990. A psycholinguistic interpretation of pauses in spontaneous utterances. In: Acta Linguistica Hungarica $40: 449-65$.

Smith, Bruce L.-Mary K. Kenney 1999. A longitudinal study of the development of temporal properties of speech production: Data from 4 children. In: Phonetica 56:73-102.

Tingley, B. M.-G. D. Allen 1975. Development of speech timing control in children. In: Child Development $46: 186-94$.

Walker, J. F. - L. Archibald-S. R. Cherniak- V. G. Fish 1993. Articulation rate in 3- and 5-year-old children. In: Journal of Speech and Hearing Research 35 : 4-14.

Wiese, Richard 1984. Language production in foreign and native languages: Same different? In: Dechert et al. $(1984,11-25)$.

Address of the author: Krisztina Menyhárt

Research Institute for Linguistics

Hungarian Academy of Sciences

Benczúr u. 33.

H-1068 Budapest

menyhart@nytud.hu 